\title{
ON WHETHER ‘DOROBO’ WAS A FOURTH KULIAK LANGUAGE
}

\author{
Terrill Schrock \\ SIL Uganda
}

\begin{abstract}
Wayland's (1931) description of a northeastern Ugandan people called the 'Wanderobo' includes thirty-eight 'Dorobo' words, many of which resemble words in Ik, the last thriving member of the Kuliak (Rub) subgroup. Because of this resemblance, it has been speculated that 'Dorobo' might have been a fourth, now extinct Kuliak language (e.g. Heine 1976). Unfortunately, this notion has persisted in the literature up to recent times. This paper examines the information found in Wayland 1931 from several perspectives to argue that 'Dorobo' was at most a dialect of Ik, not a separate language. From an anthropological perspective, the 'Wanderobo' that Wayland described match in many ways the Ik of today. From a sociolinguistic perspective, the Ik living today in the area visited by Wayland are often mixed with members of other neighboring tribes, such as the Dodoth or Toposa (Eastern Nilotic). Thus it is likely that the Ik were mixed up with them in the 1930s as well. Furthermore, the linguistic data may be unreliable: Wayland was not a linguist, and his transcriptions were adversely affected by having been acquired through interpreters speaking only broken Swahili. These three strands of evidence coincide to render the 1931 document insufficient evidence on which to establish a 'Dorobo' language.
\end{abstract}

Keywords: Doboro, Kuliak, Ik, Nilo-Saharan, Nilotic

\section{Introduction}

The Kuliak (Rub) language subgroup, considered by many to belong in Nilo-Saharan (cf. Schrock 2014), consists of three languages: So (Tepeth), Nyang'i, and Ik. All three are spoken in the region of Karamoja in northeastern Uganda. When the warlike pastoralist Teso-Turkana (Eastern Nilotic) peoples invaded the region hundreds of years ago, the Kuliak-speakers were forced to retreat into the hills and mountains where they remain to this day. The Teso-Turkana peoples not only took over many land resources but also exerted considerable cultural and linguistic pressure on Kuliak. Two of the Kuliak languages, So (Tepeth) and Nyang'i, have largely succumbed to that pressure and have become moribund. Ik, on the other hand, has managed to survive and is still thriving.

In 1931 E.J. Wayland published his "Preliminary Study of the Tribes of Karamoja" (Wayland 1931). His paper records the anthropological observations he made during his third trip into the region, taken "for the purpose of geological reconnaissance" (1). In the study Wayland describes various relatively well-known tribes like the Labwor, Jie, Dodoth, as well as a more mysterious group putatively called 'Wanderobo' or 'Dorobo'. Wayland's description is of interest to Kuliak studies because the group (and language) he calls 'Dorobo' closely resembles modern-day Ik in numerous ways. Because of the resemblance, scholars have long wondered whether 'Dorobo' was a fourth, now extinct Kuliak language (e.g. Heine 1976, Carlin 1993, Blench 2006). 
The aim of this article is to argue that 'Dorobo' was not a fourth Kuliak language but was in fact Ik, or at least a dialect of what has been considered Ik. ${ }^{1}$ It seems likely that Wayland had come across the Ik people but had simply gotten a general Swahili name for them. This unfortunate twist of fate perpetuated over the next seventy-plus years the possibility of a 'lost' Kuliak tribe. Given the evidence presented here, it seems fitting to put to rest the question of 'Dorobo' as a fourth, now extinct Kuliak language. The following sections lay out the argument by presenting evidence from anthropology, sociolinguistics, linguistics, and a common-sense evaluation of what Wayland's article had to offer.

\section{Anthropological evidence}

In the rocky hills northeast of the Dodoth people (a Karimojong sub-group), Wayland found a 'hill people' who "live in the rough mountainous country on the edge of the Karamoja-Turkana escarpment ... in places difficult of access" (212). This is exactly where the Ik live today. Figure 1 below, taken from Wayland 1931 (p. 189), shows a map of the area attributed to the 'Wanderobo' (superimposed circle added by this author). The map is followed by Figure 2, a Google Earth satellite image in which Ik villages are marked with white pins (as of December 2012). Wayland's map centers the Wanderobo population a little farther north than the Ik of today, but this was well before the northern Ik were evicted from Kidepo Valley and forced to congregate on Mount Morungole (which is where the left-most cluster of white pins is found in Figure 2).

In Figure 2, Kidepo Valley is the light patch of land northwest (upper left) of the Morungole villages. According to Wayland, the Ik inhabited the rough mountainous region just to the east of Kidepo Valley. Oral histories gathered by the author in 2011 from elderly Ik confirm that the Ik used to live in that area and hunt in Kidepo but were forced out in the 1960s by the British colonial administration (cf. also Arensen 1983). As such, it seems likely that the 'Wanderobo' that Wayland found in 1931 in the mountains east of Kidepo were the forebears of the Ik who now live on and around Mt. Morungole.

\footnotetext{
${ }^{1}$ Serzisko reached this same conclusion, stating the following: "Dorobo (Wayland 1931), das aber auch nur eine Variant des Ik sein könnte,...” (1992:7).
} 
Figure 1: Location of 'Wanderobo' in 1931

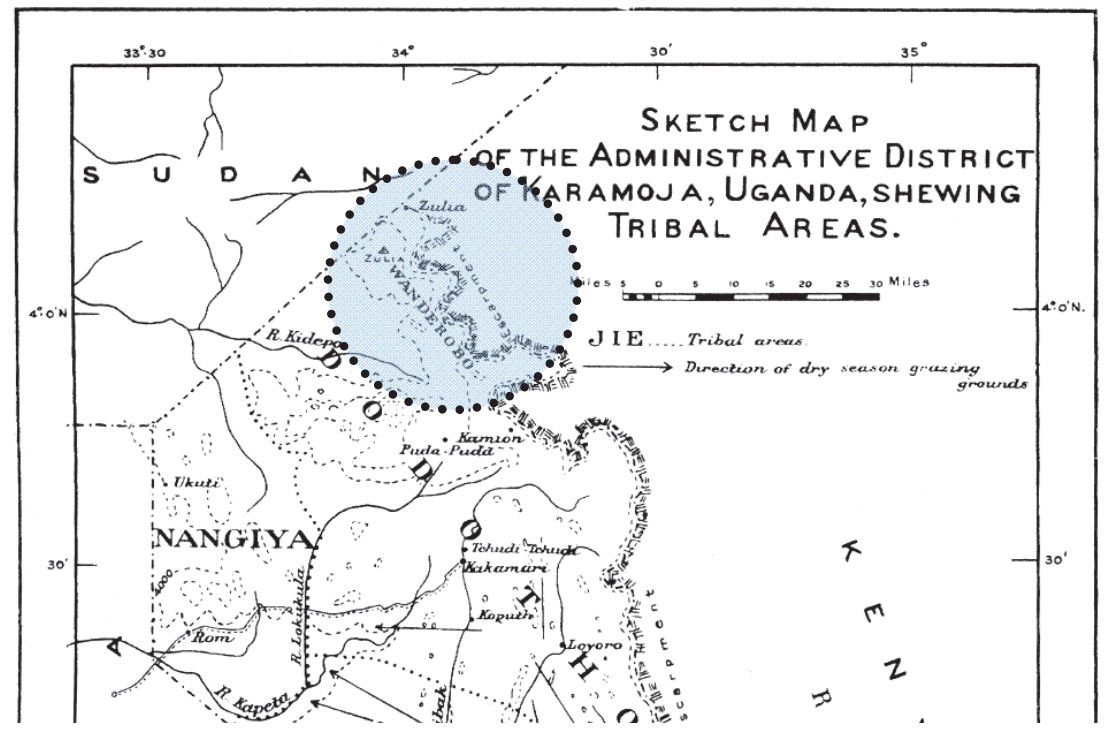

Figure 2: Location of Ik in 2012

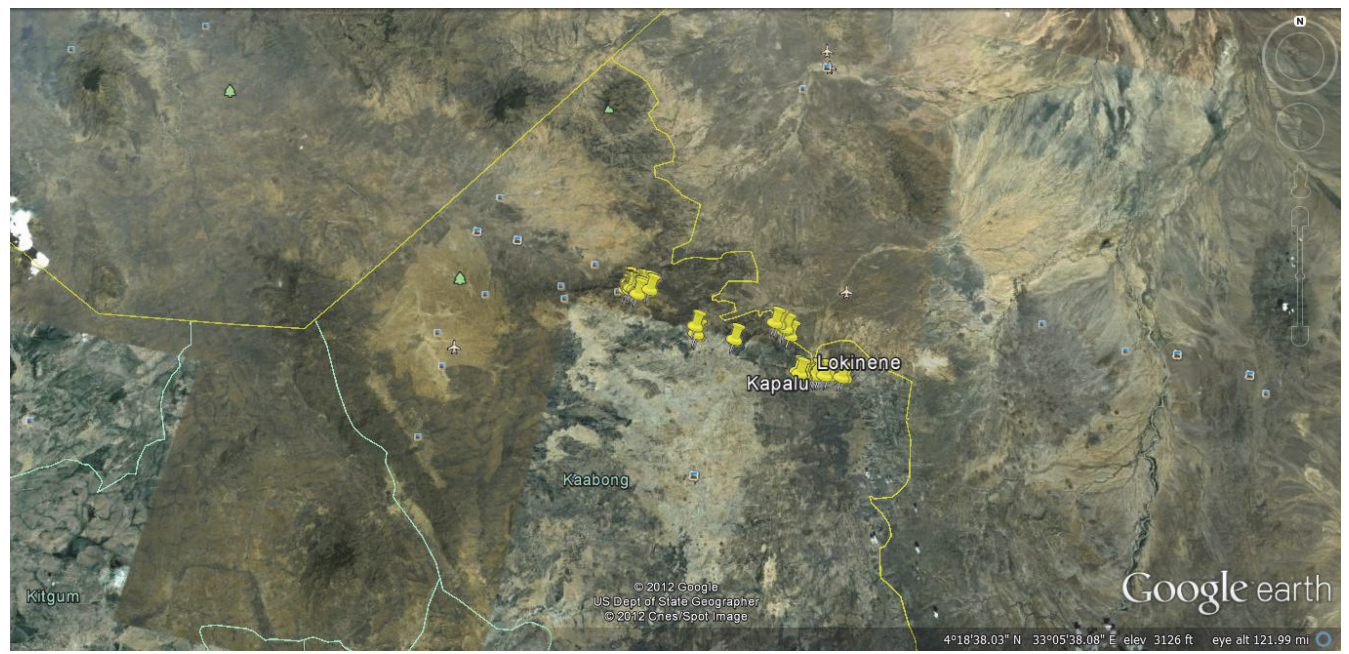

Wayland goes on to say that the Wanderobo were despised by the Dodoth and called 'monkeymen'. This accords with what the author has heard repeated over the last six years, that many Dodoth used to look down on the Ik as inferior and referred to them as yicomin 'baboons' because of their ability to spot enemies from a distance, scamper over rocks, and disappear quickly. Moreover, the Wanderobo's habit of aiding both sides of the cattle-raiding conflict between the 
Dodoth and the Turkana is well documented (that is, as Ik; see Turnbull 1972). Finally, Wayland mentions that the Wanderobo are smaller in stature than the surrounding peoples. Impressionistically, this is also true of today's Ik.

Wayland's description of Ik homes accords well with both Dodoth and Ik building styles, which are very similar (the Ik having borrowed the style). Both contain houses made of sticks, mud, and grass thatching, surrounded by a thick fence of sticks and thorns. The Dodoth homesteads differ from the Iks' in that they often include a central corral area for livestock (the Ik no longer have livestock). But of particular importance is Wayland's comment that the Wanderobo build their homes "on the edge of a very steep or precipitous slope" (213). Unlike the Dodoth, the Ik of today often do the same to make approaching their home difficult for 'enemies' and to make escaping from them easier.

\section{Sociolinguistic evidence}

Much of what Wayland recounts about the Wanderobo seems to be a mix of Kuliak and TesoTurkana culture and language. In the area outlined as the Wanderobo habitat (Figure 1 above), the people in question would have been bordered by the Toposa to the north, the Turkana to the east, and the Dodoth to the south and west. So not only would these groups have exerted cultural and linguistic influence on the 'Wanderobo' by virtue of being neighbors, but that particular area was and still is to some extent a corridor of cattle-raiding between the Teso-Turkana groups. Thus members of these groups would have been regularly crisscrossing the area, interacting with the 'Wanderobo', trading with them, and even intermarrying with them (as they increasingly do today). In such a sociolinguistic situation, the more vulnerable group (i.e. the 'Wanderobo') would likely have borrowed words, especially as they became more and more bilingual.

A very similar situation is observed today, particularly in the more northern Ik-speaking areas. Consider, for example, the Ik who live on Mount Morungole. They themselves occupy the higher reaches of the mountain, while Dodoth take residence on the lower slopes to be nearer to their herds of livestock. Both groups interact daily, giving Dodoth language and culture a chance to influence the Ik. For this reason, the Ik spoken in the northern half of the Ik area includes a higher percentage of Teso-Turkana loans.

As shown below, all the words except for four in Wayland's 'Dorobo' wordlist can be attributed to either 1) poorly-transcribed and/or translated Ik or 2) direct Teso-Turkana borrowings. Thus, not only could Wayland's informants have been Ik people who spoke Ik with Teso-Turkana influence, but they may even have been a genetic mix of Kuliak and Teso-Turkana. In sum, if Wayland went to the northern part of the 'Wanderobo' population (which seems the case, according to Figure 1), he most likely found himself in the midst of a melting pot of Kuliak and Teso-Turkana peoples and languages.

\section{Linguistic evidence}

Linguistic evidence against the notion of a fourth Kuliak language comes from two sources: 1) the etymology of the term 'Dorobo', and 2) Wayland's 'Dorobo' word-list.

The Eastern Nilotes are cattle-keepers and view cattle as true wealth. Because of this, they tend to view non-cattle-keepers as poor and therefore inferior. For example, the Jie and Turkana call 
the Kuliak groups Dikúlyâk, while the Dodoth call them Diteusó, both of which mean essentially 'poor people without cows'.

Likewise, the term 'Dorobo' purportedly comes from the Maasai (also Eastern Nilotic) word Il-toróbó (sg. Ol-torróboni) meaning 'hunter; one without cattle'. Many of the hunter-gatherer groups flanking the Maasai along the Eastern Rift Valley were seen by the Maasai as poor and therefore lumped under the umbrella category of Il-toróbó. The titles 'Dorobo' or 'Wanderobo' have been borrowed into some dialects of Kenyan Swahili and have been used to refer to any number of minority groups bordering the Maasai. These groups include ones from the Southern Nilotic, South Cushitic, and East Cushitic language families. Though the Ik do not at present border the Maasai, they do border their Eastern Nilotic cousins: the Toposa, Turkana, and Dodoth. In light of this, calling the Ik the 'Wanderobo' would have been quite natural for the pidginSwahili-speaking interpreters that Wayland had along with him on his journey through Karamoja.

On this score, Wayland writes:

The methods of investigation employed are those rightly discouraged by anthropologists; they are, however, the best that could be adopted in the circumstances. Information was obtained either direct or by interpretation, the language used being Kiswahili, for no English, or other European tongue, is understood by the natives. During recent years, a number of the Karamojan folk have picked up an ungrammatical form of Kiswahili from the troops...I had two such men in my caravan and an official Karamojong-Kiswahili interpreter; the latter, an Acholi, proved almost useless for the purpose in view (188).

So it can seem from this excerpt that conversations between Wayland and the so-called 'Wanderobo' had to take place either a) through broken pidgin Swahili or b) first through Karimojong or Toposa and then through broken Swahili. With this less than ideal interpretive situation in view, it seems quite possible that the self-referring ethnonym of these 'hill people' never made it to Wayland's ears in the first place. More likely, the pidgin-Swahili term for a small, hunter-gatherer type group living as neighbors to pastoralists on the edge of the Rift Valley was substituted for it.

Finally, it has been suggested that the Ik word for 'people' $\left(r o b^{a}\right)$ may have been heard and misinterpreted as 'Dorobo'. In both the ablative or copulative cases, the word rò $b^{a}$ appears as ròbòò in clause-medial environments. So although less plausible, this explanation deserves some consideration.

The second kind of linguistic evidence is more direct, coming from the word-list itself. Wayland mentions nine words in the text preceding the word-list, while the word-list itself contains twenty-nine words, making a total of thirty-eight 'Dorobo' words available for analysis. Commenting on these thirty-eight words, Heine claimed that "a comparison shows that there can be hardly any doubt that this language belongs to the Kuliak group, being especially closely related to Ik" (1976:4), and further:

It seems ... unlikely that Wayland's Dorobo was a language identical with present-day spoken Ik. Of the 34 items having the same meanings only 13 are cognates. Even if one takes into account that the language has changed since then, and that Wayland was not always able to get the correct equivalent, it appears that we are dealing with two different languages or two very divergent dialects of one language (1976:5). 
Contrary to this view of Heine 1976, the following discussion seeks to show that 'Dorobo' was certainly not a separate Kuliak language and was at least a dialect of Ik (perhaps even an idiolect) influenced by Teso-Turkana. To that end, the following section presents a word-by-word examination of Wayland's word-list. First, the word-list is given in its entirety (Table 1) just as Wayland recorded it (with the addition of nine words from his prose descriptions). Then an explanation is offered for why each word can be attributed to either Ik or Teso-Turkana, showing at last that 'Dorobo' was either a) Ik inaccurately elicited and/or transcribed, or b) a dialect (or idiolect) of Ik influenced by the sociolinguistic context outlined above. 
Table 1: 'Dorobo' word-list

\begin{tabular}{|c|c|c|}
\hline$\#$ & 'Dorobo' & Wayland's English gloss \\
\hline 1 & alup & earth \\
\hline 2 & bathugotak & death \\
\hline 3 & biss & spear \\
\hline 4 & bugaten & marriage \\
\hline 5 & chewe & village \\
\hline 6 & chiok & ox \\
\hline 7 & chithwe & cold \\
\hline 8 & chwt & monkey \\
\hline 9 & dack & tree \\
\hline 10 & dubu & elephant \\
\hline 11 & emm & meat \\
\hline 12 & eyeth & ant (black) \\
\hline 13 & fotara & hill \\
\hline 14 & guass & rock \\
\hline 15 & gwa & bird \\
\hline 16 & ho (yakai) & hut \\
\hline 17 & iwiatan & fight (to) \\
\hline 18 & kesen & shield \\
\hline 19 & kuu & grass \\
\hline 20 & loichetto & time of much rain \\
\hline 21 & lorara & time of rain \\
\hline 22 & loukwung & time of light rain (planting season) \\
\hline 23 & mes & beer \\
\hline 24 & nekicholong & head-rest \\
\hline 25 & nunem & semsem \\
\hline 26 & nyaburrigi & Indian corn \\
\hline 27 & nyadis & sky \\
\hline 28 & nyamaroni & wizard \\
\hline 29 & nyep & snake \\
\hline 30 & ripp & millet \\
\hline 31 & saba & valley \\
\hline 32 & se & blood \\
\hline 33 & sthut & hot \\
\hline 34 & takaik & sandal \\
\hline 35 & watt & rain \\
\hline 36 & yangalolo & river \\
\hline 37 & yokoliya & fish \\
\hline 38 & zibera & hoe \\
\hline
\end{tabular}

Each of the items in Table 1 above is discussed in turn below:

1. alup (earth)-from Karimojong/Toposa yalup 'soil, earth'. Word-initial velar nasals are sometimes a bit hard to hear in Teso-Turkana languages, even for a trained linguist. They may 
even be softened or left off in casual speech (a process lexicalized in the southern Teso-Turkana language Ateso).

2. bathugotak (death)—from Ik badukoták ${ }^{a}$ [bād̄ūk'ōtáka] 'S/he/it has died'. The Ik /d/ is farther forward than the English /d/, sometimes to the point where it sounds almost inter-dental. The Ik velar ejective $/ \mathrm{k}^{\prime} /$ has a velar implosive $/ \mathrm{g} /$ as a frequent allophone, especially in rapid or casual speech. If an Ik speaker was heavily influenced by Teso-Turkana, the ejective might start giving way to the implosive. This may have been heard as a voiced velar implosive $/ \mathrm{g} /$ or even as a voiced velar plosive $/ \mathrm{g} /$. As to the meaning, the difference between Wayland's gloss and the Ik gloss suggests the correct grammatical category (verb instead of noun) got lost in the process of translation through Swahili.

3. biss (spear)—from Ik bIs [6̄̄s:] 'spear'. Ik vowels are reduced before pauses, and this environment would include items in a list. If the consonant following the reduced vowel is a fricative, the reduction results in the loss of the vowel and the phonetic lengthening of the fricative. This may explain how Wayland transcribed this item. And as already seen from (2) above, the transcriber seemed to lack knowledge of implosives.

4. bugaten (marriage)—from Ik bokatín [bōk'ātín] 'bride'. The Ik velar ejective with a voiced velar implosive as a common allophone was probably mistaken for the voiced velar stop $/ \mathrm{g} /$. The transcription of vowels seems problematic, both in this example and in many others. As for the gloss, it looks like the subject of marriage was broached but may have taken a different direction through the process of translation.

5. chewe (village)-This is more challenging: possibly from Ik cue [t $\mathrm{f}$ ūe] 'water'. It is remotely conceivable that in the process of pointing to various things in the vicinity to get their names in 'Dorobo', a village was confused with a water source.

6. chiok (ox)—from Ik cúrúk [tfúrúka] 'male (any animal)'. Ik children often omit word-medial /r/ as when maráy 'It is good' becomes mayán. The transcription suggests that the word was misheard or that the one speaking it also dropped the $/ \mathrm{r} /$. It is interesting to note that the same word in Nyang'í also lacks /r/: kîk or kiúk (Heine 1976:45).

7. chithwe (cold)—from Ik cucue [t $\mathrm{t}$ ùt $\left.\int \bar{u} e.\right]$ 'moist chill'. In this and the previous item, it looks like [+ATR] high back vowels were heard as high front vowels. This is understandable, since even in modern Ik there is often considerable vowel assimilation between vowels like $/ \mathrm{i} / \mathrm{l}$ and $/ \mathrm{u} /$, for example when $\dot{n} c i-k^{o} \rightarrow \dot{n} c u-k^{o}$ 'It is I.'

8. chwt (monkey)-This origin of this item is still totally unknown. Since this item strangely has no vowel, perhaps it involves a transcriptional or typographical error?

9. dack (tree)—from Ik $d a k w^{a}$ [d్̄ākwa] 'tree'. Word-final devoiced vowels in Ik can be hard to perceive, especially if one is unaware of their existence. 
10. $d u b u$ (elephant)—The only possible nominal source in Ik would be dób [d this could be established (which it cannot), one can only speculate as to the semantic relationship. ${ }^{2}$ From the Ik verbal lexicon, one possibility is dób [d dôb] 'catch'. Perhaps in miming how an elephant grabs things with its trunk, the sequential verb dóbò̀ (non-final form) or dób j̀k (final form) '... and it catches/caught'.

11. emm (meat)-from Ik em [ēm] 'meat'.

12. eyeth (black ant)-possibly from Ik $\varepsilon s[\bar{\varepsilon} \mathrm{s}:]$ 'termite(s)'. Speakers of Karimojong often pronounce $[\mathrm{s}],[\mathrm{z}],[\theta]$ and $[ð]$ in free variation. If one of Wayland's translators or informants was Teso-Turkana, he could have easily rendered $\varepsilon s$ as eyeth.

13. fotara (hill)—from Ik fátár [fátár] 'vertical ridge'.

14. guass (rock)—from Ik gwas [gwās:] 'stone, rock'.

15. gwa (bird)—from Ik $g w a$ [gwā $\left.\overline{\mathrm{h}}^{\mathrm{h}}\right]$ 'bird'.

16. ho/yakai (hut)—from Ik ho [hō $\overline{\mathrm{h}}^{\mathrm{h}}$ 'hut' and Karimojong akai 'hut'.

17. iwiatan (to fight) - This one is challenging, but possibly based on the Ik verb root $i w$ [iw] 'hit' as in the simple clause iwiáta $n t^{a}$ meaning 'They usually hit'.

18. kesen (shield)—from Ik kesen [kēsēn] 'shield'.

19. $k u u$ (grass) - from Ik $k \grave{u}^{a}$ [kùa] 'grass'. The doubling of /u/ may have been intended to capture the devoiced vowel at the end of the word (in the nominative case).

20. loichetto (time of much rain)—from Ik lotséto [1ōtsétō] 'month of bad honey' or directly from Karimojong locoto (one of the months of the year). The Ik have borrowed Teso-Turkana names for months of the year and adapted them to Ik phonology (for example, Teso-Turkana $/ \mathrm{t} f / \rightarrow / \mathrm{ts} /$ in $\mathrm{Ik})$.

21. lorara (time of rain) - from Karimojong lorara (month of the year), which in modern-day Ik has the form of raraan (month approximating December).

22. loukwung (time of light rain)—from Karimojong lokway (month of planting), found also in Ik. As to the substitution of $/ \mathrm{u} /$ for $/ \mathrm{a} /$ in the final syllable, personal experience has shown that Anglophones may occasionally mishear and mispronounce the central /a/ as a more reduced vowel like $/ \mho /$ or even $/ \mathrm{\partial} /$.

23. mes (beer)-from Ik mès [mغ̀s:] 'beer'.

${ }^{2}$ Although in Uduk, the word jè means both 'elephant' and 'mud' with only a difference in grammatical gender (Don Killian, pc). Further historical studies may uncover the semantic connection. 
24. nekicholong (head-rest)—from Toposa nekicoloy 'head-rest/stool'. The initial palatal nasal, transcribed here as an alveolar nasal, is obligatory in Toposa and Northern Turkana and optional in other Teso-Turkana languages in most environments.

25. nunem (semsem) - The origin of this item is still unknown, and it would be a stretch to get it from Karimojong ekanyum or Ik kanum, both of which mean 'simsim (sesame seeds)'.

26. nyaburrigi (Indian corn)—from Ik nabura [nābōrā] 'maize' and/or Toposa neburai 'maize' (from which the Ik term was likely borrowed). The transcription here is odd and cannot be easily deduced from either the Ik or the Teso-Turkana parallel. One idea is that the word-final /i/ in both languages, if fully voiced, may co-occur with a light [ç] sound (cf. Heine 1999:17). This may have been perceived as the consonant $/ \mathrm{g} /$.

27. nyadis (sky) - from Toposa nadis 'sky', possibly borrowed into Ik as nadis 'sky', a substitute for the older Ik word for 'sky': didi-gwari 'weather-top'.

28. nyamaroni (wizard)—from Toposa nemuron 'witchdoctor'.

29. nyep (snake)-This item is still unknown, the closest (and admittedly unlikely) possibility being the Ik onerep [ōyērēpa] 'Rufous beaked snake'.

30. ripp (millet)—from Ik réb [rêb'] 'finger millet'. Word-final voiced consonants in Ik are devoiced before a pause. This would explain why $/ \mathrm{b} /$ was interpreted as $/ \mathrm{pp} /$.

31. saba (valley)—from Ik sàbà [sàbà] 'river'. One can imagine pointing down into a valley with a river and getting the Ik word for 'river' instead of 'valley' (fòts in Ik).

32. se-from Ik sè [sè] 'blood'.

33. sthut (hot)-from Ik $t s^{\prime} \hat{u} d$ [ts' $\left.\mathrm{u} d \mathrm{n}\right]$ 'smoke'. The alveolar ejective /ts'/ is transcribed here as 'sth'. And as already mentioned, word-final voiced consonants in Ik are partially devoiced before a pause. So the final $/ \mathrm{d} /$ of $t s^{\prime} \hat{u} d$ sounds a lot like $/ \mathrm{t} /$ in actual pronunciation. In terms of the translation, one can easily imagine pointing to a fire to get the word for 'hot' and instead getting the word for 'smoke'.

34. takaik (sandal)—from Ik takáík [tāk'áíka] 'sandals', singular takát.

35. watt (rain)—from Ik wat ${ }^{a}$ [wātă 'rain' (either as a noun or a verb).

36. yangalolo (river)-from Toposa nayolol 'river'.

37. yokoliya (fish)—from Toposa nokolya 'fish (sg.)', with an Ik reflex as $\eta k o ́ l i ́ a$. 
38. zibera (hoe)—from Ik dzibér [dzībér] 'axe'. It is easy to mishear the initial voiced affricate of this item, leaving off the /d/. Even some Ik with strong idiolects leave off the initial sound of these word-initial affricates. As for the gloss, a situation can be easily imagined in which a hoe is confused with an axe through poor translation.

In summary, out of the total of 38 'Dorobo' lexical items recorded by Wayland, 23 can be reasonably attributed to $\mathrm{Ik}, 5$ to Teso-Turkana, 6 to a mix of both (i.e. the source could have been either language), and 4 to an unknown source. Words belonging to each category can be divided up as follows:

Table 2: Percentage of word-list items according to etymology

\begin{tabular}{l|l}
\hline Ik words $(60 \%)$ & Teso-Turkana words $(16 \%)$ \\
\hline bathugotak & alup \\
biss & nekicholong \\
chewe & nyadis \\
chiok & nyamaroni \\
chithwe & yangololo \\
dack & yokoliya \\
emm & \\
\cline { 2 - 2 } eyeth & Teso-Turkana/Ik words (borrowed through Teso-Turkana; 13\%) \\
\cline { 2 - 2 } fotara & ho/akai (ho is Ik; akai is Teso-Turkana) \\
guass & loichetto \\
gwa & lorara \\
iwiatan & loukwung \\
kesen & nyaburrigi \\
kuu & \\
\cline { 2 - 2 } mes & Words of unknown origin (11\%) \\
ripp & chwt \\
saba & dubu \\
se & nyep \\
sthut & nunem \\
takaik & \\
watt & \\
zibera & \\
& \\
& \\
&
\end{tabular}

The percentages indicated in Table 2 demonstrate that 'Dorobo' consisted predominantly of Ik with mildly high levels of influence from Teso-Turkana. These influences can be attributed to dialectal or even idiolectal factors at the time and place of elicitation. Readers are invited to make suggestions on the origin of the unknown items!

\section{Conclusion}

To conclude, Wayland's word-list appears to be plagued by problems both in translation and transcription. This is not surprising since Wayland himself admitted to the "scrappiness of the 
information collected" (188). And this is no fault of his; no one should reasonably expect a nonlinguist to gather accurately transcribed linguistic data (at least by today's standards). By the same token, the existence of a 'Dorobo' language should not be founded on such a document alone, yet this is the only source of data on this mysterious lect. But with the combination of anthropological, sociolinguistic, and linguistic evidence presented above, the question of whether 'Dorobo' was a fourth Kuliak language can be answered in the negative. 'Dorobo' was not a fourth, now extinct Kuliak language. At most it was a dialect or even an idiolect of Karamoja's last thriving Kuliak tongue Ik.

\section{References}

Arensen, Jonathan. 1983. Sticks \& Straw: Comparative house forms in Southern Sudan and Northern Kenya. SIL: Dallas, TX.

Blench, Roger M. 2006. Archaeology, Language and the African Past. Lanham: Altamira Press.

Carlin, Eithne. 1993. The So Language. (Afrikanistische Monographien 2). Institut für Afrikanistik. Universität zu Köln: Köln.

Heine, Bernd. 1976. The Kuliak languages of Eastern Uganda. Nairobi: East African Publishing House.

Heine, Arensen, Jonathan. 1983. Sticks \& Straw: Comparative Bernd. 1999. Ik-English dictionary. Rüdiger Köppe Verlag: Köln.

Schrock, Terrill. 2014. A grammar of Ik (Icé-tód): Northeast Uganda's last thriving Kuliak language. Utrecht: LOT.

Turnbull, Colin. 1972. The mountain people. New York: Simon \& Schuster.

Wayland, E.J. 1931. Preliminary studies of the tribes of Karamoja. Journal of the Royal Anthropological Institute, 61: 187-230.

Terrill Schrock

SIL Uganda

terrill_schrock@sil.org
Received: 31 Aug 13

Accepted: 22 Nov 13

Corrections: 14 Sept 14 